\title{
Front Matter: Volume 7301
}

, "Front Matter: Volume 7301," Proc. SPIE 7301, Technologies for Synthetic Environments: Hardware-in-the-Loop Testing XIV, 730101 (18 May 2009); doi: $10.1117 / 12.833371$

SPIE Event: SPIE Defense, Security, and Sensing, 2009, Orlando, Florida, United SPIE. States 


\section{PROCEEDINGS OF SPIE}

\section{Technologies for Synthetic Environments: \\ Hardware-in-the-Loop Testing XIV}

James A. Buford, Jr.

Robert Lee Murrer, Jr.

Editors

13 April 2009

Orlando, Florida, United States

Sponsored and Published by

SPIE

Volume 7301 
The papers included in this volume were part of the technical conference cited on the cover and title page. Papers were selected and subject to review by the editors and conference program committee. Some conference presentations may not be available for publication. The papers published in these proceedings reflect the work and thoughts of the authors and are published herein as submitted. The publisher is not responsible for the validity of the information or for any outcomes resulting from reliance thereon.

Please use the following format to cite material from this book:

Author(s), "Title of Paper," in Technologies for Synthetic Environments: Hardware-in-the-Loop Testing XIV, edited by James A. Buford, Jr., Robert Lee Murrer, Jr., Proceedings of SPIE Vol. 7301 (SPIE, Bellingham, WA, 2009) Article CID Number.

ISSN 0277-786X

ISBN 9780819475671

Published by

SPIE

P.O. Box 10, Bellingham, Washington 98227-0010 USA

Telephone +1 3606763290 (Pacific Time) · Fax +1 3606471445

SPIE.org

Copyright (C) 2009, Society of Photo-Optical Instrumentation Engineers

Copying of material in this book for internal or personal use, or for the internal or personal use of specific clients, beyond the fair use provisions granted by the U.S. Copyright Law is authorized by SPIE subject to payment of copying fees. The Transactional Reporting Service base fee for this volume is $\$ 18.00$ per article (or portion thereof), which should be paid directly to the Copyright Clearance Center (CCC), 222 Rosewood Drive, Danvers, MA 01923. Payment may also be made electronically through CCC Online at copyright.com. Other copying for republication, resale, advertising or promotion, or any form of systematic or multiple reproduction of any material in this book is prohibited except with permission in writing from the publisher. The CCC fee code is 0277-786X/09/ $\$ 18.00$.

Printed in the United States of America.

Publication of record for individual papers is online in the SPIE Digital Library.

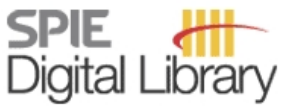

SPIEDigitalLibrary.org

Paper Numbering: Proceedings of SPIE follow an e-First publication model, with papers published first online and then in print and on CD-ROM. Papers are published as they are submitted and meet publication criteria. A unique, consistent, permanent citation identifier (CID) number is assigned to each article at the time of the first publication. Utilization of CIDs allows articles to be fully citable as soon they are published online, and connects the same identifier to all online, print, and electronic versions of the publication. SPIE uses a six-digit CID article numbering system in which:

- The first four digits correspond to the SPIE volume number.

- The last two digits indicate publication order within the volume using a Base 36 numbering system employing both numerals and letters. These two-number sets start with 00, 01, 02, 03, 04, $05,06,07,08,09,0 A, 0 B \ldots 0 Z$, followed by 10-1Z, 20-2Z, etc.

The CID number appears on each page of the manuscript. The complete citation is used on the first page, and an abbreviated version on subsequent pages. Numbers in the index correspond to the last two digits of the six-digit CID number. 


\section{Contents}

vii Conference Committee
ix Introduction

SESSION 1 FLIGHT MOTION SIMULATORS

730102 Gimbal stability requirements for target image enhancement [7301-01]

R. W. Mitchell, Ideal Aerosmith, Inc. (United States)

730103 Making flight motion tables invisible [7301-02]

L. A. DeMore, Point Park Univ. (United States); P. Hollinger, G. Hirsh, Acutronic USA, Inc. (United States)

730104 General characteristics of motion simulators used in the performance tests of infrared camera systems [7301-03]

B. Özkan, A. Akmeşe, TÜBITAK Sage (Turkey)

\section{SESSION 2 HWIL FACILITIES AND TEST}

730105 Support technologies involved in the development and implementation of radiometric systems for sensor calibration, characterization, and HWIL testing at AEDC [7301-04]

H. S. Lowry, M. F. Breeden, D. H. Crider, S. L. Steely, R. A. Nicholson, J. M. Labello, Arnold Air Force Base (United States)

730106 Digital video timing analyzer for the evaluation of PC-based real-time simulation systems [7301-05]

S. R. Jones, J. L. Crosby, Optical Sciences Corp. (United States); J. E. Terry, Jr., U.S. Army Aviation and Missile Research (United States)

730107 Common hardware-in-the-loop development [7301-06]

H. J. Kim, U.S. Army RDECOM (United States); S. G. Moss, AEgis Technologies Group, Inc. (United States)

730108 The infrared and semi-active laser simulation capabilities at the AMSTAR production bay HWIL Facility [7301-07]

C. L. Talbot, D. Saylor, S. Wilkerson, Optical Sciences Corp. (United States); W. Lowry, U.S. Army Redstone Technical Test Ctr. (United States); J. Morris, U.S. Army AMRDEC (United States)

\section{SESSION 3 REAL-TIME SCENE GENERATION I}

730109 Comparison of GPU and FPGA hardware for HWIL scene generation and image processing [7301-08]

C. R. Eales, L. Świerkowski, Defence Science and Technology Organisation (Australia) 
7301 OA Boat, wake, and wave real-time simulation [7301-09]

L. Świerkowski, E. Gouthas, C. L. Christie, O. M. Williams, Defence Science and Technology Organisation (Australia)

$7301 \mathrm{OB}$ Real-time volumetric rendering and compositing techniques for high-altitude wake scene generation [7301-10]

D. H. Bunfield, D. E. Trimble, Davidson Technologies Inc. (United States); G. H. Ballard, U.S. Army Aviation and Missile Research (United States)

\section{SESSION 4 REAL-TIME SCENE GENERATION II}

7301 OC Using GPU convolutions to correct optical distortion in closed-loop real-time missile simulations [7301-11]

T. Fronckowiak, Jr., Torch Technologies (United States) and U.S. Army Aviation and Missile Research (United States)

7301 OD Digital tapped delay lines for HWIL testing of matched filter radar receivers [7301-12] R. F. Olson, U.S. Army Aviation and Missile Research (United States); W. J. Braselton, Boeing Service Company (United States); R. D. Mohlere, Simulation Technologies, Inc. (United States)

\section{SESSION $5 \quad$ IR PROJECTORS}

7301 OE Two-band DMD-based infrared scene simulator [7301-13]

J. R. Dupuis, D. J. Mansur, R. Vaillancourt, T. Evans, D. Carlson, E. Schundler, OPTRA, Inc. (United States)

7301 OF MIRAGE WF infrared scene projector system, with 1536 × 768 wide format resistive array, performance data [7301-14]

K. Sparkman, J. LaVeigne, J. Oleson, G. Franks, S. McHugh, Santa Barbara Infrared, Inc. (United States); J. Lannon, RTI International (United States); B. Woode, D. Greer, NAWCAD (United States); N. Bui, US Army (United States)

$7301 \mathrm{OH} \quad$ Liquid crystal on silicon spatial light modulator for infrared scene generation [7301-16] J. Stockley, K. Bauchert, A. Linnenberger, S. Serati, Boulder Nonlinear Systems, Inc. (United States); C. Vuong, U.S. Army PEO STRI (United States)

7301 Ol Effects of indium mole fraction on LWIR light-emitting device performance [7301-17] N. C. Das, Army Research Lab. (United States); F. Towner, R. P. Leavitt, Maxion Technologies, Inc. (United States)

7301 0J VLSI-Membrane-Mirror-Light-Modulator scene projection technology [7301-18] T. Simpkins, J. Hui, M. Whitson, C. Warde, Optron Systems, Inc. (United States)

\section{SESSION 6 PROJECTOR CALIBRATION}

7301 OK Spectral calibration of a visible projector [7301-19]

M. H. Bowden, D. B. Beasley, Optical Sciences Corp. (United States); D. S. Cosby, U.S. Army AMRDEC (United States) 
7301 OL Rise-time enhancement techniques for resistive array infrared scene projectors [7301-20] G. Franks, J. LaVeigne, K. Sparkman, J. Oleson, Santa Barbara Infrared, Inc. (United States)

$73010 M \quad$ Resistor array infrared projector nonuniformity correction: search for performance improvement IV [7301-21]

L. Świerkowski, R. A. Joyce, O. M. Williams, Defence Science and Technology Organisation (Australia)

Author Index 
Downloaded From: https://www.spiedigitallibrary.org/conference-proceedings-of-spie on 26 Apr 2023

Terms of Use: https://www.spiedigitallibrary.org/terms-of-use 


\title{
Conference Committee
}

\author{
Symposium Chair
}

Ray O. Johnson, Lockheed Martin Corporation (United States)

Symposium Cochair

Michael T. Eismann, Air Force Research Laboratory (United States)

Conference Chairs

James A. Buford, Jr., U.S. Army Aviation and Missile Research, Development and Engineering Center (United States)

Robert Lee Murrer, Jr., Millennium Engineering and Integration Company (United States)

Program Committee

Mary A. Amick, U.S. Air Force (United States)

James A. Annos, U.S. Navy (United States)

David B. Beasley, Optical Sciences Corporation (United States)

Dennis H. Bunfield, Davidson Technologies Inc. (United States)

Charles F. Coker, Air Force Research Laboratory (United States)

David S. Cosby, U.S. Army Research, Development and Engineering Command (United States)

Naresh C. Das, Army Research Laboratory (United States)

Shawn M. Goodrich, U.S. Air Force (United States)

Alexander G. Hayes, MIT Lincoln Laboratory (United States)

W. Larry Herald, MacAulay Brown Inc. (United States)

John M. Lannon, RTI International (United States)

Heard S. Lowry, Aerospace Testing Alliance (United States)

Scott B. Mobley, U.S. Army Aviation and Missile Research, Development and Engineering Center (United States)

Randy A. Nicholson, Aerospace Testing Alliance (United States)

Robert M. Patchan, The Johns Hopkins University Applied Physics Laboratory (United States)

Ronald J. Rapp, Air Force Research Laboratory (United States)

Jonathan C. Reeves, U.S. Air Force (United States)

Donald R. Snyder, Air Force Research Laboratory (United States)

Steven L. Solomon, Acumen Scientific (United States)

Owen M. Williams, Defence Science and Technology Organisation (Australia)

Brian K. Woode, Naval Air Warfare Center (United States) 
Session Chairs

$1 \quad$ Flight Motion Simulators

James A. Buford, Jr., U.S. Army Aviation and Missile Research,

Development and Engineering Center (United States)

2 HWIL Facilities and Test

Scott B. Mobley, U.S. Army Aviation and Missile Research, Development and Engineering Center (United States)

Brian K. Woode, Naval Air Warfare Center (United States)

Alexander G. Hayes, MIT Lincoln Laboratory (United States)

3 Real-Time Scene Generation I

Charles F. Coker, Air Force Research Laboratory (United States)

David S. Cosby, U.S. Army Research, Development and Engineering Center (United States)

Robert M. Patchan, The Johns Hopkins University, Applied Physics Laboratory (United States)

4 Real-Time Scene Generation II

John M. Lannon, RTI International (United States)

W. Larry Herald, MacAulay Brown Inc. (United States)

Dennis H. Bunfield, Davidson Technologies Inc. (United States)

$5 \quad$ IR Projectors

James A. Buford, Jr., U.S. Army Aviation and Missile Research,

Development and Engineering Center (United States)

Robert Lee Murrer, Jr., Millennium Engineering and Integration

Company (United States)

Ronald J. Rapp, Air Force Research Laboratory (United States)

Robert W. Mitchell, Ideal Aerosmith, Inc. (United States)

6 Projector Calibration

Owen M. Williams, Defence Science and Technology Organisation

(Australia)

Naresh C. Das, Army Research Laboratory (United States)

Heard S. Lowry, Aerospace Testing Alliance (United States) 


\section{Introduction}

Beyond this page you will find the proceedings of the 14th conference of Technologies for Synthetic Environments: Hardware-in-the-Loop Testing. After thirteen years, I have handed over Chair duties to Jim Buford and I will continue on as his co-chair. Given the continued strong interest (in the form of papers and attendance) in this conference, we will assume we have a winning formula and so the fundamental theme and format will remain unchanged.

In these proceedings, you will find a refreshing variety of papers from flight motion simulators, to test facility integration, to innovations in scene generation, to infrared projector technology and characterization. We have achieved the standard in infrared projection with the maturation of the Santa Barbara Infrared resistor arrays but much work remains. Many have achieved remarkable success in non-uniformity correction performance but there remain nagging unknowns with respect to annealing characteristics of the emitter materials. Emitter overdrive has re-emerged as a discussion topic to significantly improve rise time. PCscene generators have become the standard and innovative techniques have resulted in previously impossible real-time dynamic modeling of the interaction of a target with its environment (i.e. boat wakes, aero-wakes, and plumes).

We are eternally thankful to the authors and presenters who face competing interests for their time while navigating the creep of scrutiny on release authority. Many thanks also to Kathryn Stevens who was the motor behind the pleadings and urgings as deadlines came and went; without her support, this conference would not have been possible.

James A. Buford, Jr. Robert Lee Murrer, Jr. 
Downloaded From: https://www.spiedigitallibrary.org/conference-proceedings-of-spie on 26 Apr 2023

Terms of Use: https://www.spiedigitallibrary.org/terms-of-use 